\title{
DIRECT MARKETING METHOD IS PREFERRED BY THE PEOPLE DUE TO THE IMPACT CORONA VIRUS IN THE AHMEDNAGAR
}

\author{
Prof. Dr. Pakhale Kishor \\ Incharge principal \& assistant professor in commerce, Ashwamedh arts commerce night college, \\ Ahmedngar
}

Article DOI: https://doi.org/10.36713/epra7230

DOI No: 10.36713/epra7230

\begin{abstract}
-ABSTRACT
Due to coronavirus disease, the world facing confusing and critical situation! Under this circumstance to government is first aim is to keep away the people from this. Government as a solution for this to keep a people is getting a safe the governments of all country are preferred lockdown. In the lockdown people are not permit to get out the house.in the lockdown people are how to fulfill his daily purchasing need and what the purchasing resources they are use in the pandemic situation. This study will suggest the people use to direct marketing and his tools in the pandemic disease situation, without going anywhere. In this study used mintab18 and SPSS software to testing, z-test and correlation testing method used.
\end{abstract}

KEYWORDS:-direct marketing, corona virus, covid-19, lockdown.

\section{INTRODUCTION}

COVID-19 is the disease caused by a new coronavirus called SARS-CoV-2. WHO first learned of this new virus on 31 December 2019, following a report of a cluster of cases of 'viral pneumonia' in Wuhan, People's Republic of China? The scientist is working in that time. They were suggested the name of these diseases is call as a corona virus or covid-19. ("Coronavirus Disease (COVID-19)" n.d.)

These dieses dangerous affect the human body, the lot of cases the very critical situation arises. The most common symptoms of COVID-19 are

- Fever

- Dry cough

- Fatigue

Other symptoms that are less common and may affect some patients include:

- Loss of taste or smell,

- Nasal congestion,

- Conjunctivitis (also known as red eyes)

- Sore throat,

- Headache,

- Muscle or joint pain,

- Different types of skin rash,

- Nausea or vomiting,

- Diarrhea,

- Chills or dizziness.

Symptoms of severe COVID-19 disease include:

- Shortness of breath,

- Loss of appetite,

- Confusion,

- Persistent pain or pressure in the chest, 
- $\quad$ High temperature (above $38^{\circ} \mathrm{C}$ ).

- Other less common symptoms are:

- Irritability,

- Confusion,

- Reduced consciousness (sometimes associated with seizures),

- Anxiety,

- Depression,

- Sleep disorders,

- More severe and rare neurological complications such as strokes, brain inflammation, delirium and nerve damage. ("Coronavirus Disease (COVID-19)" n.d.)

People of all ages who experience fever and/or cough associated with difficulty breathing or shortness of breath, chest pain or pressure, or loss of speech or movement should seek medical care immediately. If possible, call your health care provider, hotline or health facility first, so you can be directed to the right clinic.("Coronavirus Disease (COVID-19)" n.d.)

Not being able to speak or move these problems seen in the people. This virus is affected directly our immunity power. There is no perfect vaccination is in corona virus the virus is transfer person to person very easily, In this way corona virus are speeded easily, the effect of corona virus country are seal his boundary, Because the infected people did not come. Virus infection the world is stop. No one can going here and there.

The various country governments are creating a lockdown to stop the spreading corona virus dieses.

Against the corona virus dieses the WHO (world health organization) declare that the corona virus is world pandemic dieses. To the rescue from him they were created some rules for a people and people are following these rule.

Given the impact of corona virus some of the government and WHO are generate the some rules is to help to Avoid corona virus they have gave the advice to people to ware mask in public place ,create social distance, washing hand with soap frequently and stay at home

Government has advice to the people refuse to get out of the house and go to the market and to refuse to visit the crowded area. The government are created lockdown, In that point of view no one can going here and there to purchase the product .No one can get out of the outside the home. They have only permission to purchase daily need product or regular needed product.

The pandemic situation of corona virus people are using safe channel to purchase the product they are choice to purchase the old channels like manufacture -distributor-wholesaler -retailer-customers or in the direct marketing channels like manufacture -customers. In this method there are only two people. But the old channels is more than two person involve.

In the against, the corona the direct marketing is suitable channels. This study will help to find out which is suitable to people or who is preferred the people.

1.1. Direct marketing

In the year 1958 the direct marketing was coined by Lester Wanderman. Direct marketing is promotional method and personal selling.in this method there is only two parties involve. There is no middle man is present in the trading.

- TV

- Radio

- Mobile

- Social Ads

- $\quad$ Email marketing

- $\quad$ SMS

- Telemarketing

- Personal selling or face to face marketing

- Kiosk

\section{LITERATURE REVIEW}

(Karaxha, Tolaj, and Abazi 2016)accordingly this researcher The paper consists of two parts: the first part is related to the review of literature regarding direct marketing, and the second part is related to the research conducted through surveys in companies, by interviewing the director, general manager, marketing manager and managers of other departments within the company who have knowledge about the marketing in the company. This study regarding direct marketing and its role in relation with consumers is an interesting field to study, but at the same time it is also a challenge, because knowing more about one technique or another is a field on its 
own and requires the analysis of particular specifics of each technique in order for the direct marketing to have a positive impact in creating good relations with the clients on the basis of fulfilling their needs and requests.

(Abraham and Joseph 2019)is says that the Direct marketing tries to build up and exploit a direct relationship between the seller and its prospect. Direct marketing occurs when businesses address customers through a multitude of channels, including mail, e-mail, phone, and in person. The results of such campaigns are immediately measurable, as a business can track how many customers have responded through a message's call to action.in his study in present scenario of digitalization; direct marketing is used by marketers to develop close relationship with each customer in order to achieve the loyalty of customers. The purpose of this study was to explore direct marketing as the most effective form of marketing.

(Pham, Do Thi, and Ha Le 2020)says his aims to discover how online shoppers react to their purchasing behavior during Covid-19 time in terms of perceived benefits perspective. Based on the collected data from 427 Vietnamese online respondents during the social distancing period due to Covid-19, the research analyses the role of Covid-19 as a moderator variable in the relationship between benefits perception of the consumer and their online shopping activity. The result shows Covid-19 plays a moderating role in consumer's awareness of utilities, which encourages shoppers towards online shopping. However, the affection of society could be a reason that consumers become more hesitant to shop online.

(Junusi 2020)according to this the article aims to determine the prospects and effects of digital marketing in the pandemic period and develop the concept of digital marketing from an Islamic perspective. The methodology of this article uses a descriptive qualitative approach by analyzing various literatures on digital marketing. The results of this study found that advances in information technology played a role in the development of digital marketing, especially during the Covid-19 Pandemic.

(Hoekstra and Leeflang 2020) the researchers discuss the effects of COVID-19 on consumer behavior and elaborate on the consequences of this disruption for marketing strategies and marketing policies. It also displays characteristics which differ from down cycles, such as shifts in consumption between categories and the accelerated shift from offing to online behavior. This is forced by the re-evaluation of life priorities by final consumers.

(Elrod and Fortenberry 2020) says Direct marketing is one of the most recognized forms of marketing communication, thanks in large part to its widespread use and direct engagement of consumers. While some applications clearly have the potential to irritate consumers (e.g., junk mail in post boxes, spam in email inboxes), direct marketing can be deployed in manners respectful of recipients and, in such cases, it can prove to be a helpful communications asset. To aid others in understanding this particular conveyance method, this article presents an overview of direct marketing and shares deployment insights and experiences from WillisKnighton Health System.

(Mason, Narcum, and Mason 2021) This exploratory research examines how the COVID-19 pandemic led to increases in consumers' social media marketing behaviors in the United States. the findings demonstrate the growing importance of social media marketing since the COVID-19 pandemic began. Given that the COVID-19 pandemic is a global phenomenon, the findings likely can be extrapolated across many nations. Suggestions are provided to help businesses adopt to changes in consumers' social media behaviors as they relate to the consumer decision-making processes.

\section{RESEARCH GAP}

There are large numbers of researcher is analyzing and explanation the theory of covid -19.This study studied collective direct marketing and the recue corona pandemic disease. How people are purchase and satisfy daily needs which market they are going. Which method they are using in pandemic situation to secure his life?

1. To explain the direct marketing and his tools.

\section{OBJECTIVE}

2. To analysis overall order placing and purchasing method.

\section{HYPOTHESIS}

1. There is a more than $50 \%$ people are purchasing through the direct marketing.

2. There is a positive relation between used direct marketing tool and purchase order direct marketing tools to pandemic situation. 


\subsection{Sampling}

\section{DATA ANALYSIS}

Direct marketing method is preferred by the people due to the impact corona virus in the Ahmednagar. This study is a descriptive in a nature and data is qualitative data. cochran's formula is using for select of sample. In that there are select the 370 random sampling.

\subsection{Data collection}

Direct marketing method is preferred by the people due to the impact corona virus in the Ahmednagar. This study collect the data in two ways first is primary data and second is secondary data.The data collection through surveys method of 370 customer who are using online and offline purchasing in ahmednagar. The questionnaire is circulating 370 people and gives the 10 minute to each customer fills up the questionnaire.

6.3. Data interpretation

One-Sample Z: response

Descriptive Statistics

Table I

\begin{tabular}{|c|c|c|c|c|}
\hline $\mathbf{N}$ & Mean & StDev & SE Mean & $\begin{array}{c}\text { 95\% Upper Bound } \\
\text { for } \boldsymbol{\mu}\end{array}$ \\
\hline 370 & 1.2201 & 0.4149 & 0.0216 & 1.2556 \\
\hline
\end{tabular}

$\mu$ : mean of response

Known standard deviation $=0.414320$

Test

Table II

\begin{tabular}{|c|c|}
\hline Null hypothesis & $\mathrm{H}_{0}: \mu=50$ \\
\hline Alternative hypothesis & $\mathrm{H}_{1}: \mu<50$ \\
\hline
\end{tabular}

Table III

\begin{tabular}{|c|c|}
\hline Z-Value & P-Value \\
\hline-2258.55 & 0.000 \\
\hline
\end{tabular}

In the table name One-Sample Z: response Descriptive Statistics Table I the mean value is 1.2201 standard deviation values is $0.4149 \mathrm{SE}$ Mean is 0.0216.in the Table III p-value is 0.000 the result is statistically significant. In this table III p-value is $(0.001)$ is less than 0.05 the result would be statistically significant and we would accept the alternative hypothesis. Accept H1:- There is a more than $50 \%$ people are purchasing through the direct marketing.

\section{Correlations}

Table IV

\begin{tabular}{|ll|c|c|}
\hline & & $\begin{array}{c}\text { purchase order } \\
\text { used direct } \\
\text { marketing tool }\end{array}$ & $\begin{array}{c}\text { direct marketing } \\
\text { tool }\end{array}$ \\
\hline used direct marketing tool & Pearson Correlation & 1 & $-.112^{*}$ \\
& Sig. (2-tailed) & & .032 \\
& $\mathrm{~N}$ & 370 & 370 \\
\hline purchase order direct marketing tool & Pearson Correlation & $-.112^{*}$ & 1 \\
& Sig. (2-tailed) & .032 & 370 \\
$\mathrm{~N}$ & & 370 \\
\hline
\end{tabular}

*. Correlation is significant at the 0.05 level (2-tailed).

In this table, used direct marketing tool and purchase order direct marketing tool Pearson correlation is $.112^{*}$. There is used direct marketing tool and purchase order direct marketing tool is correlation to each other 
because the sig. (2-tailed) value 0.032 is less than 0.05 there is correlation. In this table Pearson correlation is .112 the value is minus there is negative correlation. The value of sig.(2-tailed) is significant. Reject the null hypothesis and accept alternative Hypothesis. Accept H1. There is a positive relation between used direct marketing tool and purchase order direct marketing tools to pandemic situation.

\section{CONCLUSION}

The Concluded that in the coronavirus dieses the direct marketing tools is very important because provide risk free purchasing. This is the better way to survive the infection of infected people. Customers are stay at home and place the purchase order using direct marketing tools. Direct marketing tool are also available in online and offline. The direct marketing tools are easily using all people. This method is provide the product direct manufacture to customer and remove traditional marketing channels.

\section{REFERENCES}

1. Abraham, Varghese, and Jerin Joseph. 2019. "An Empirical Study on Direct Marketing As the Most Effective Form of Marketing in the Digitalized Marketing Environment." () International Journal of Research Science \& Management 18 (1): 18-24. https://doi.org/10.5281/zenodo.2536255.

2. “Coronavirus Disease (COVID-19)." n.d. Accessed May 27, 2021. https://www.who.int/emergencies/diseases/novel-coronavirus-2019/question-and-answers-hub/q-adetail/coronavirus-disease-covid-19.

3. Elrod, James K., and John L. Fortenberry. 2020. "Direct Marketing in Health and Medicine: Using Direct Mail, Email Marketing, and Related Communicative Methods to Engage Patients." BMC Health Services Research. https://doi.org/10.1186/s12913-020-05603-w.

4. Hoekstra, Janny C., and Peter S. H. Leeflang. 2020. "Marketing in the Era of COVID-19." Italian Journal of Marketing 2020 (4): 249-60. https://doi.org/10.1007/s43039-020-00016-3.

5. Junusi, Rahman El. 2020. "Digital Marketing During the Pandemic Period; A Study of Islamic Perspective." Journal of Digital Marketing and Halal Industry 2 (1): 15. https://doi.org/10.21580/jdmhi.2020.2.1.5717.

6. Karaxha, MSc. Halit, MSc. Sejd Tolaj, and Dr.Sc. Arjan Abazi. 2016. "The Role of Direct Marketing in Relation with the Consumers in Kosovo.” ILIRIA International Review 6 (1): 49. https://doi.org/10.21113/iir.v6i1.223.

7. Mason, Andrew N., John Narcum, and Kevin Mason. 2021. "Social Media Marketing Gains Importance after Covid-19." Cogent Business and Management 8 (1). https://doi.org/10.1080/23311975.2020.1870797.

8. Pham, Van Kien, Thu Ha Do Thi, and Thu Hoai Ha Le. 2020. "A Study on the COVID-19 Awareness Affecting the Consumer Perceived Benefits of Online Shopping in Vietnam." Cogent Business and Management 7 (1). https://doi.org/10.1080/23311975.2020.1846882. 